\title{
STAT3 activation is required for the antiapoptotic effects of prolactin in cervical cancer cells
}

\author{
Adrián Ramírez de Arellano 1,2, Edgar I. Lopez-Pulido³, Priscila A. Martínez-Neri1,2, Ciro Estrada Chávez ${ }^{4}$, \\ Renee González Lucano ${ }^{5}$, Mary Fafutis-Morris ${ }^{2}$, A. Aguilar-Lemarroy ${ }^{6}$, José. F. Muñoz-Valle ${ }^{7}$ \\ and Ana Laura Pereira-Suárez ${ }^{2^{*}}$
}

\begin{abstract}
Background: Prolactin (PRL) has been implicated in the development of different types of cancer. However, signaling pathways might be activated depending on various forms of prolactin receptor (PRLR). JAK/STAT is an important pathway associated with PRL effects. The activation of JAK/STAT pathway might activate antiapoptotic genes that could importantly lead to progression of tumorigenesis. Recently, we have reported that PRL is associated with cell survival by inhibition of apoptosis and the precise activated signaling pathways for this process are still questioned. The purpose of this study was to evaluate the activation of different signaling pathways in response to PRL as well as to identify the induction of antiapoptotic genes.
\end{abstract}

Methods: Cervical cancer cell lines HeLa, SiHa and C-33 A were stimulated with PRL (200 ng/mL) for 30 and 60 min and non stimulated cells were used to measure basal protein expression. Inhibition assays were performed by using Jak2 specific inhibitor AG490, either alone or in combination with PRL for $48 \mathrm{~h}$. Western blot were carried out to evaluate protein induction of the different signaling pathways and antiapoptotic proteins. Significant effects were determined by using ANOVA test.

Results: STAT3 was significantly activated in cervical cancer lines in comparison with non-tumorigenic keratinocytes $\mathrm{HaCaT}$. No significant differences were found when analyzing MAPK and PI3K signaling pathways. An increase of antiapoptotic genes $B C l-x l, B C l-2$, survivin and $M C l-1$ was observed after stimulus with $P R L$; however, after inhibition with AG490, the induction of antiapoptotic genes was decreased.

Conclusion: Our data suggests that STAT3 is an important signaling pathway activated by PRL in cervical cancer cells and it modulates the induction of antiapoptotic genes. Blocking STAT3 could represent a possible therapeutic strategy in cervical cancer.

Keywords: PRL, Cervical cancer, STAT3

\section{Background}

Prolactin (PRL) is a peptidic hormone with diverse biological effects such as cell proliferation, immunoregulation, osmoregulation and reproduction. PRL is synthesized mainly by the pituitary gland. However,

\footnotetext{
*Correspondence: analauraps@hotmail.com

${ }^{2}$ Laboratorio de Inmunología, Departamento de Fisiología, Centro Universitario de Ciencias de la Salud, Universidad de Guadalajara, Sierra Mojada \# 950, Colonia Independencia, 44340 Guadalajara, Jalisco, Mexico Full list of author information is available at the end of the article
}

other cell types have the capacity to produce PRL in an autocrine-paracrine manner acting as a growth factor, neurotransmitter and inmunomodulator [1]. These functions are the result of PRL binding to prolactin receptor (PRLR) activating the signaling pathways Janus kinase/ Signal transducer and activator of transcription (JAK/ STAT), Mitogen-activated protein kinases (MAPK) and phosphoinositide 3 kinase (PI3K). Several forms of PRLR have been described including a long form, an 
intermediate form and two short forms, each of them with the ability to activate different signaling pathways [2-4].

It has been documented that the activated signaling by PRL/PRLR is associated with tumor development. The association of PRL and its receptor with tumor progression was first established on animal models many decades ago [5]. Recently, there are several studies that involve PRL in the development of different types of cancer such as breast $[6-8]$, prostate $[9,10]$, ovarian $[11]$ and cervical $[12,13]$.

With regard to cervical cancer we reported an overexpression of PRLR and the presence of different forms in tissues derived from cervical cancer in comparison with premalignant lesions and healthy tissues [12]. This accumulation in the cytoplasm could be due to alterations in PRLR leading to a decrease of PRLR phosphorylation and subsequent lack of ubiquitination which is associated with the non-degradative process and as a result, the accumulation of PRLR [14]. In addition, we reported that PRL and PRLR induction is associated with cell survival, mainly by inhibition of apoptosis, but not by inducing proliferation, in cervical cancer cell lines [15].

It has been documented that the activation of these signaling pathways induces the induction of target genes associated with proliferation and antiapoptotic effects in breast cancer [16]. However, there are no investigations focused on the induction of antiapoptotic genes in cervical cancer in response to PRL/PRLR.

For this reason, the purpose of this study was to evaluate the signaling pathways involved in the antiapoptotic effect mediated by PRL/PRLR in cervical cancer, as well as the induction of antiapoptotic genes that could be subserving the development of the carcinogenic process.

\section{Materials and methods Reagents}

Prolactin (L-4021) was obtained from Sigma-Aldrich ${ }^{\circledR}$. Polyvinylidenedifluoride (PVDF) membranes, enhanced chemi-luminiscence (ECL), Western blotting detection kit (WBKLS0500), and monoclonal antibody anti-actin (Clone C4) were purchased from Merck Millipore ${ }^{\circledR}$ (EMD Millipore Corporation Billerica, MA, USA). Polyclonal antibodies anti-pSTAT3 (Ser 727) sc-13564, anti-STAT3 (H-190) sc-7179, anti-pERK 1/2 (Thr 202) sc-101760, anti-pAKT $1 / 2 / 3$ (ser 473) sc-101629, anti-AKT 1/2/3 (H-136) sc-8312 as well as the monoclonal antibodies anti-ERK2 (H-9) sc-271451, anti-bcl-xl (H-5) sc-8392 and anti-bcl-2 (C-2) sc-7382 were obtained from Santa Cruz Biotechnology ${ }^{\circledR}$, inc (Santa Cruz, CA). Phospho-p38 (Thr 180/Tyr 182) (D3F9) \#4511 and p38 MAPK \#9212 were purchased from Cell Signaling Technology ${ }^{\circledR}$ (Danvers, MA, USA). Polyclonal antibody anti-survivin AF886 was purchased from R\&D Systems ${ }^{\circledR}$ (R\&D Systems, inc. Minneapolis, Mn). Inhibitor for JAK/STAT signaling pathway $\alpha$-cyano-(3,4-dihydroxy)- $N$-benzylcinnamide (AG490) was dissolved in dimethyl sulfoxide (DMSO) and stored at $-20{ }^{\circ} \mathrm{C}$ as recommended by the manufacturer. RPMI 1640, DMEM and Fetal Bovine Serum (FBS) were purchased from Gibco ${ }^{\circledR}$, Life technologies (Carlsbad, CA).

\section{Cell culture}

Cervical cancer derived cells (HeLa, SiHa, C-33A), as well as breast cancer derived cells overexpressing PRLR (MCF-7, T-47D), and non-tumorigenic immortalized keratinocytes $(\mathrm{HaCaT})$ from American Type Culture Collection ${ }^{\circledR}$ (University Boulevard Manassas, VA) were used. All cells were grown with RPMI 1640 or DMEM medium supplemented with $5 \%$ of Fetal Bovine Serum (FBS), penicillin G, streptomycin and amphotericin B. Media, FBS, antibiotic and antimicotic were obtained from Gibco $^{\circledR}$, Life technologies (Carlsbad, CA).

Cells were cultured in a jacket-water incubator at $37{ }^{\circ} \mathrm{C}$ with an atmosphere of $5 \% \mathrm{CO}_{2}$. All cells were grown to reach $80 \%$ confluence so they were used for assays.

The investigation was approved by the ethical investigation and biosecurity committee of the University Center of Health Sciences at the University of Guadalajara (Reference Number C.I. 093/13 CUCS).

\section{Prolactin stimuli and protein extraction}

Cells were seeded in 6-well plates and stimulated with $600 \mathrm{ng}$ of PRL for either 30 or $60 \mathrm{~min}$. Proteins were extracted by using $100 \mu \mathrm{L}$ RIPA buffer $(50 \mathrm{mM}$ Tris, $100 \mathrm{mM} \mathrm{NaCl}, 1 \% \mathrm{NP} 40,0.5 \%$ sodiym deoxycolate and $0.1 \%$ sulfate dodecilsulphate (SDS) in addition of a cocktail of protease inhibitors (pepstatin A, aprotinin A, chymostatin, antipain, bestatin and PSMF) as well as a phosphatase inhibitor (Na3VO4) followed by centrifigation at $4{ }^{\circ} \mathrm{C}$ for $15 \mathrm{~min}$. Protein extract concentrations were determined by using Lowry method (DC Protein Assay, BioRad Laboratories, Hercules, CA).

\section{Western blot}

Fifty micrograms of total protein extract were mixed with loading buffer and denatured at $95{ }^{\circ} \mathrm{C}$ for $5 \mathrm{~min}$. Afterwards they were loaded on $10 \%$ SDS polyacrylamide gels to be resolved. Electrotransference was carried out in polyvinylidene difluoride membranes (BioRad Laboratories, Hercules, CA). Blocking solution was prepared with $5 \%$ of Blotting Grade Blocker (BioRad Laboratories, Hercules, CA) and membranes were incubated in this solution for $2 \mathrm{~h}$. Solutions with primary antibodies were prepared at a dilution of 1:500 and 1:10,000-in the case of $\beta$-actin-and membranes were kept overnight followed by either anti-mouse or anti-rabbit secondary 
antibody solutions (diluted 1:5000). Reveal process was developed with a chemiluminiscence system (Immobilion, Merck Millipore ${ }^{\circledR}$ ). Microchemi 4.2 was used to reveal membranes and measure optical density as well.

\section{STAT3 inhibition assay}

Cells were seeded in six-well plates for $48 \mathrm{~h}$ under three conditions: no stimulus, PRL stimulus, and PRL stimulus plus AG490 inhibitor. During the time of stimuli, cells were kept at $37{ }^{\circ} \mathrm{C}$ and $5 \% \mathrm{CO}_{2}$. Once the time of stimuli was over, proteins were extracted as described above.

\section{Apoptotic assay (TUNEL assay)}

To carry out TUNEL assay we used the kit APO-BrdU (Invitrogen). Cells were grown for $24 \mathrm{~h}$ in eight-well chamber slides seeded with $5 \times 10^{4}$ cells per well were treated with etoposide alone or in combination with PRL or PRL plus AG490 for $24 \mathrm{~h}$ and incubated at $37^{\circ} \mathrm{C}$. The slides were washed with PBS and fixed with $4 \%$ paraformaldehyide for $30 \mathrm{~min}$ at room temperature. Fixed cells were washed and permeabilized by using $0.2 \%$ Tween 20 for $10 \mathrm{~min}$ and then incubated with terminal deoxynucleotidyl transferase and Brd-U for $1 \mathrm{~h}$ at $37^{\circ} \mathrm{C}$. After rinsing with PBS, cells were treated with Alexa Fluor 488 dye-labeled anti $\mathrm{BrdU}$ antibody at $37{ }^{\circ} \mathrm{C}$ for $30 \mathrm{~min}$ and mounted with a glass coverslip. Staining of DNA fragmentation was observed with ultraviolet fluorescent microscope (Carl Zeiss) counting at least 200 cells per well.

\section{Statistical analysis}

Data was analyzed by using Graph pad Prism software (Graph pad version 6.01). Significant effects were determined using ANOVA. Statistically significant differences were considered for $p$ values $<0.05$.

\section{Results}

To determine the effect of PRL on the activation of different signaling pathways in the uterine cervical cancer cell line compared to non-tumorigenic immortalized keratinocytes $\mathrm{HaCaT}$, all cell lines were stimulated with PRL during 30 and $60 \mathrm{~min}$. The MCF-7 and T-47D breast cancer cell lines overexpressing PRLR were used. Immunoblotting analysis of cellular proteins was performed to assess the induction of pS727-STAT3, STAT3, pT202ERK, ERK, pT180/pY182-p38, p38, pS473-Akt and Akt.

\section{Prolactin induces STAT3 phosphorylation in cervical cell lines}

The results showed a differential expression pattern of constitutively active pS727-STAT3 among the analyzed cell lines. In comparison to the HPV-negative C-33 A cells, SiHa and HeLa cells demonstrated a higher
pS727-STAT3 basal expression. However, treatment with PRL increased pS727-STAT3 induction in HeLa and C-33 A. In MCF-7 and T-47D, increased induction of pS727-STAT3 by the effect of PRL was also observed. In contrast, no differences at $30 \mathrm{~min}$ and a decreased pS727STAT3 expression at $60 \mathrm{~min}$ in the $\mathrm{HaCaT}$ cell line were observed (Fig. 1).

\section{Prolactin increases phosphorylation of Akt in the T-47D cell line and decreases in the C-33 A cell line}

The expression of pS473-Akt was only observed in T-47D and C-33 A cell lines. PRL induced activation of Akt in T-47D and the opposite effect was observed in C-33 A (Fig. 2).

\section{Prolactin modulates the phosphorylation of ERK and p38 in cervical and breast cancer cell lines}

The pT202-ERK expression was observed in cell lines T-47D, HeLa, SiHa, C-33 A and HaCaT. PRL stimulus induced a significant increase in the phosphorylation of ERK in T-47D, both at 30 and $60 \mathrm{~min}$; on the other hand, a downregulation of pT202-ERK induction by PRL was observed in HeLa in a time-dependent manner and in C33 A at 60 min (Fig. 3a). Moreover, a significant increase of phospho-p38 induction modulated by PRL was perceived in cell lines MCF-7, C-33 A, HeLa, SiHa and $\mathrm{HaCaT}$. The peak of p38 activation in MCF-7 and HeLa was observed at $30 \mathrm{~min}$, while in cell lines C-33 A, $\mathrm{SiHa}$ and $\mathrm{HaCaT}$, it was at 60 min (Fig. 3b).

\section{The activation of STAT3 is directly correlated to the induction of anti-apoptotic genes}

STAT3 induction in cervical cancer cell lines was the only pathway that showed activation after PRL stimulus compared to $\mathrm{HaCaT}$. Therefore, to test the functional relevance of active STAT3 in the induction of antiapoptotic genes, we inhibited the JAK/STAT pathway by using AG490 inhibitor. In order to evaluate effectively that the signaling pathway had been inhibited, the induction of pS727-STAT3 was assessed. The results showed that the increment in the PRL-mediated phosphorylation of STAT3 in the cell lines HeLa, SiHa and C-33 A was detectable $48 \mathrm{~h}$ after treatment and that co-stimulation with the AG490 reduced this effect in the three cervical cancer cell lines (Fig. 4a).

After stimulation with PRL, an increment in the level of Bcl-xl was observed in HeLa, SiHa and C-33 A and the inhibition of STAT3 diminished the induction of this anti-apoptotic molecule in all three analyzed cell lines (Fig. 4b).

On the other hand, the induction of Bcl-2 was increased in C-33 A after treatment with PRL, and inhibition of STAT3 reduced the induction in both HeLa and 


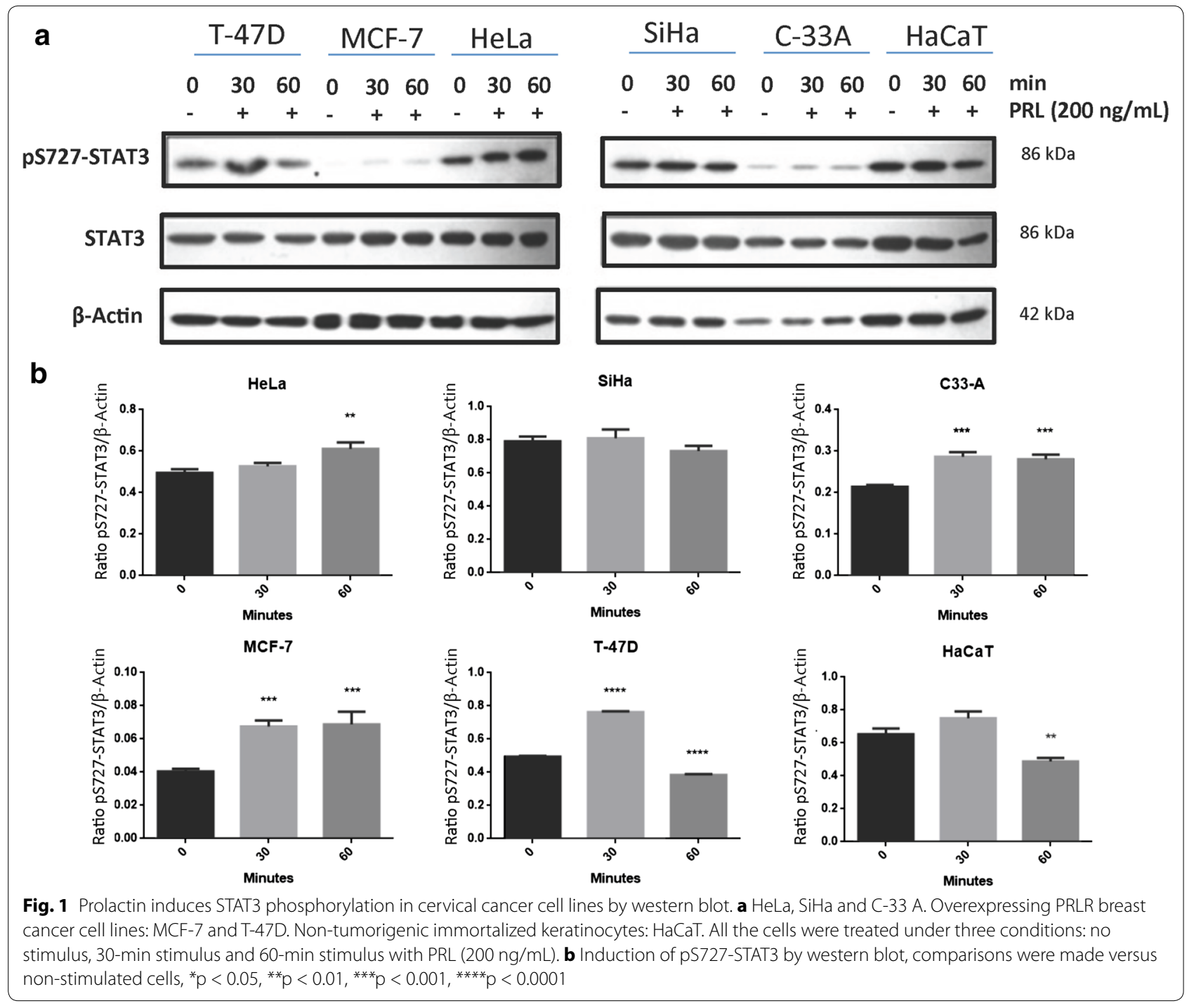

C-33 A cell lines. In the SiHa cell line, the induction of Bcl-2 was not observed. The induction of survivin was increased in the cell lines HeLa and C-33 A after stimulus with PRL and the inhibition of STAT3 reduced its induction in all three analyzed cell lines (Fig. 4b).

When analyzing Mcl-1 expression we can observe that there is a decrease in its induction when blocking STAT3 signalling in this 3 cell lines (Fig. 4b).

\section{Apoptosis is directly related to decrease of antiapoptotic genes in HeLa cells}

After stimuli with etoposide apoptosis is augmented in comparison to those non stimulated but this increase is diminished when PRL is present in the medium. Yet, after blocking JAK/STAT pathway apoptosis is restablished (Fig. 4c).

\section{Discussion}

The abnormal induction of PRL/PRLR has been associated with the development and progression of various types of cancers such as breast [17], prostate [18, 19], colorectal [20, 21], larynx [22], and hepatocellular [23, 24]. However, few studies have reported the induction of PRL/PRLR in cervical cancer, so their role has been poorly studied. A previous study reported that the presence of PRL is increased in cervical cancer tissue from patients compared with controls [25]. Additionally, an increase in serum PRL levels was reported in a considerable number of patients with cervical cancer [26]. Recently, our research group observed a high induction of PRLR in samples of patients with cervical cancer compared with samples from patients with intraepithelial lesions [12]. 


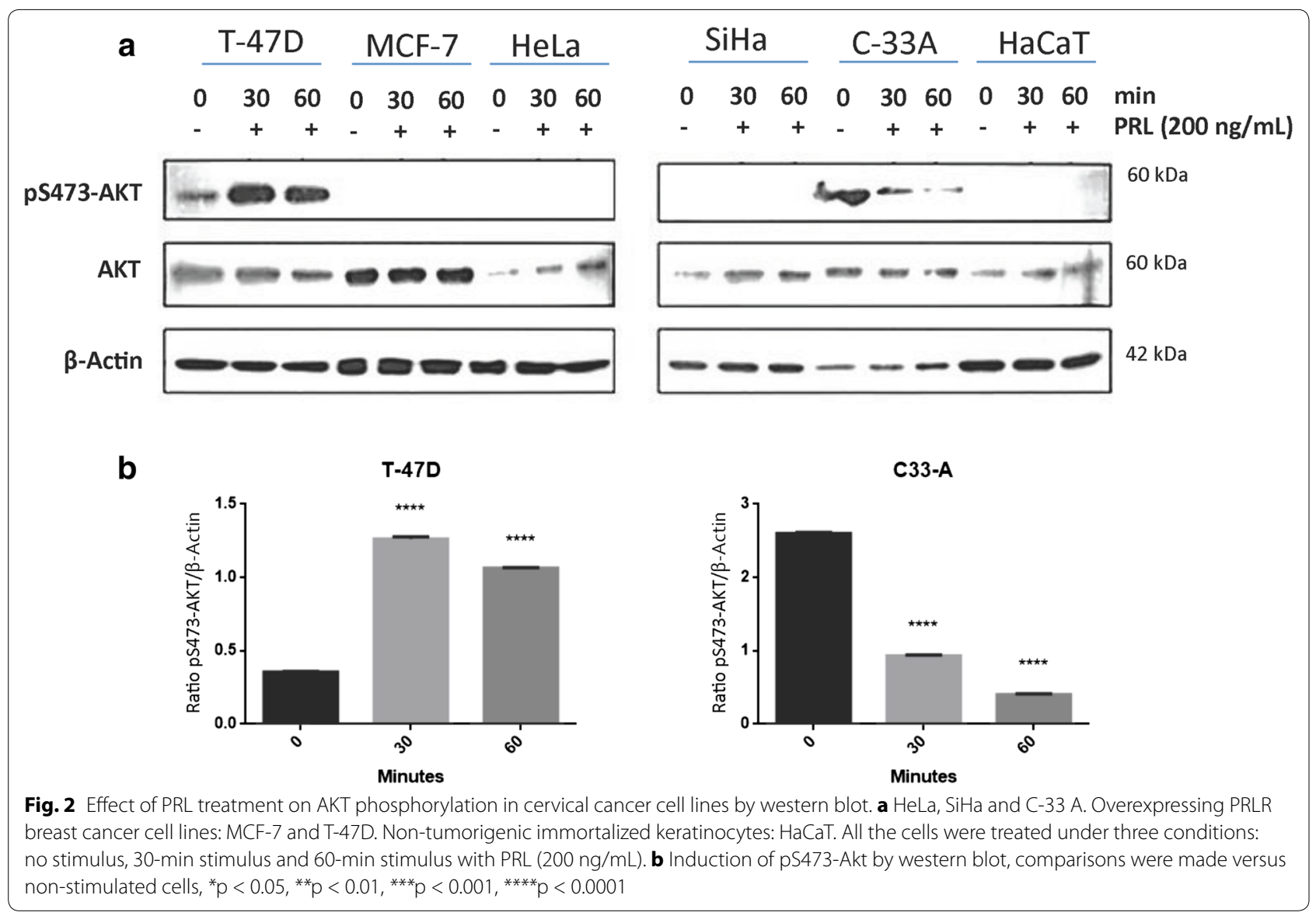

Cancer development related to PRL, is mainly described in breast cancer [27, 28]. Some authors have reported that PRL promotes the proliferation of T-47D and MCF-7 cell lines [29]. In contrast, other authors show that PRL does not have any effect on cell proliferation in the breast cancer cell lines MDA-MB-231, T-47D, MCF-7 and Hs578T [8]. These differences may be caused by the use of different techniques and culture conditions as well as different clones for each cell line. Another study, reported that treatment with PRL does not promote proliferation in PC3 and LNCaP cell lines derived from prostate cancer, but has shown a pro-apoptotic effect on the LNCaP cell line which responds to stimulation with androgens [30]. On the other hand, it has been reported that PRL stimuli prevents apoptosis after treatment with $\mathrm{C} 2$-ceramide in the breast cancer cell lines T-47D, MCF-7 and Hs578T [8].

Similar results, reported by our research group show that treatment with PRL has a protective effect against etoposide-induced apoptosis by decreasing the number of apoptotic cells in HeLa, SiHa y C33A, compared with the immortal human keratinocyte $\mathrm{HaCaT}$ cell line. This suggests that PRL plays an important role in the survival of cervical cell lines [15].
Regarding the activation of signaling pathways that modulate such effects, it has been reported that Jak2 is essential for the proliferative effects of PRL on the induction of breast tumorigenesis, however, deletion of Jak2 after neoplastic transformation, does not have an impact on survival and proliferation of breast cancer cells in culture or in vivo [6].

In the same context, PRL/PRLR signaling has the ability to promote progression and invasion in breast cancer through independent pathways to JAK2/STAT5, such as c-Src, FAK and MAPK. In addition, PRL may promote cell motility and confer resistance to chemotherapy, which contributes to metastasis $[28,31]$.

In this study, at first instance, we analyzed which signaling pathway is activated on cervical cancer cell lines after the stimulation with PRL; we observed an important increase in STAT3 phosphorylation, compared to the $\mathrm{HaCaT}$ cell line; however, no changes were observed in the activation of other signaling pathways.

Previously, and consistent with our results, it has been reported that the signaling pathway that involves STAT3 is activated constitutively in cervical cancer, this was observed in vivo on the tissue from patients as well as 

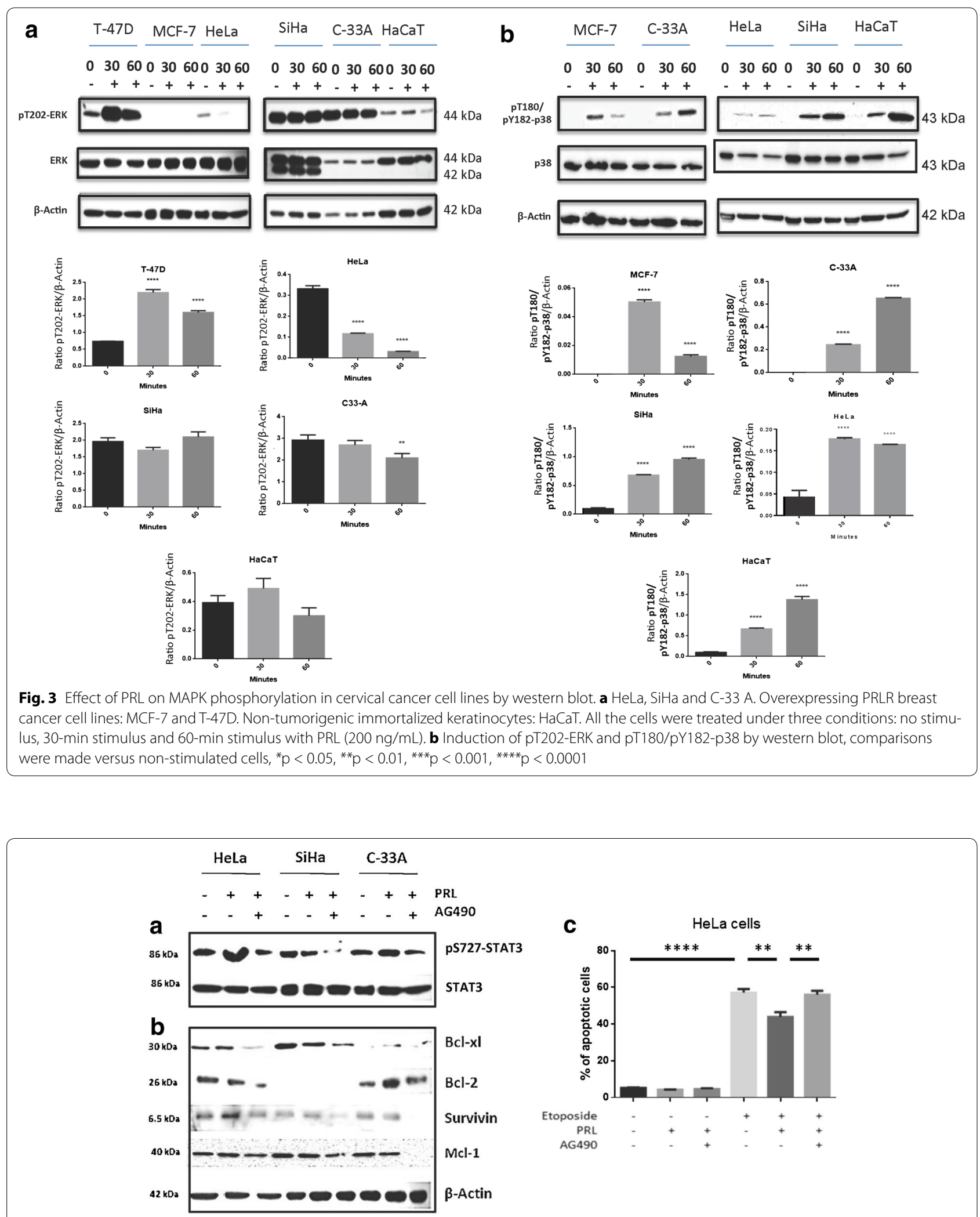

Fig. 4 Effect of PRL and AG490 on bcl-xl, bcl-2, survivin and Mcl-1 induction in cervical cancer cells. HeLa, SiHa and C-33 A were treated with either PRL alone or in combination with AG490 inhibitor. a Induction of pS727-STAT3. b Induction of antiapoptotic genes bcl-xl, bcl-2, survivin and Mcl-1. c Apoptosis in HeLa cells after stimuli with Etoposide, PRL and AG490 
in vitro on different cell lines derived from cervical cancer [32].

On the other hand, a strong positive correlation of constitutively active STAT3 with induction of HPV16 E6 and E7 oncoproteins and a negative association with levels of p53 and pRB on HPV16-positive cervical cancer cell lines ( $\mathrm{SiHa}$ and $\mathrm{CaSki}$ ) and primary tumor tissues, have been reported [33].

Furthermore, another previous work reported an overactivation of STAT3 observed in tissues from patients with cervical cancer, which is associated with increased induction of anti-apoptotic genes such as Bcl-xl, survivin and $M c l-I$ [13].

Our results further demonstrate that PRL increases the induction of $B c l-x l, B c l-2$, survivin and $M c l-1$ antiapoptotic genes. Due to activation of STAT3 and the overinduction of antiapoptotic genes found on cervical cancer cell lines after PRL stimulation, we decided to inhibit the STAT3 activation using the inhibitor AG490; which resulted in an impaired induction of $B c l-x l, B c l-2$, survivin and $\mathrm{Mcl}-1$. In order to confirm the functional effect of STAT3 activation on apoptosis of cervical cancer cell lines, TUNEL assays were carried out and we observed that there is a direct correlation between the induction of antiapoptotic genes and apoptosis.

Similar to this finding, the suppression of STAT3 induction or activation on $\mathrm{SiHa}$ and Caski was associated with the gradual loss of HPV16 E6 and E7 induction and was accompanied by the loss of cell viability [33].

\section{Conclusion}

Our findings suggest that PRL could be modulating the induction of antiapoptotic genes through STAT3 activation in cervical cancer cells, without discarding the involvement of other alternate routes to those discussed in this paper.

\section{Authors' contributions \\ ARA and ELP performed all the experimental work described in the study, searched scientific literature, and contributed with figures. JFMV contributed with scientific ideas and research. MFM participated in the design of the study and contributed to the review of the manuscript. APS conceived and designed the theoretical framework of the study, provided scientific guid- ance throughout the project and wrote the manuscript. All authors read and approved the final manuscript.}

\footnotetext{
Author details

${ }^{1}$ Ciencias Biomédicas, Centro Universitario de Ciencias de la Salud, Universidad de Guadalajara, Guadalajara, Jalisco, Mexico. ${ }^{2}$ Laboratorio de Inmunología, Departamento de Fisiología, Centro Universitario de Ciencias de la Salud, Universidad de Guadalajara, Sierra Mojada \# 950, Colonia Independencia, 44340 Guadalajara, Jalisco, Mexico. ${ }^{3}$ Departamento de Clínicas, Centro Universitario de Los Altos, Tepatitlán de Morelos, Jalisco, Mexico. ${ }^{4}$ Unidad de Biotecnología Médica y Farmacéutica, Centro de Investigación y Asistencia en Tecnología y Diseño del Estado de Jalisco A.C., 44270 Guadalajara, Jalisco, Mexico. ${ }^{5}$ Instituto Tecnológico y de Estudios Superiores de Monterrey, Campus Guadalajara, Zapopan, Jalisco, Mexico. ${ }^{6}$ Centro Médico Nacional de Occidente (CMNO), Instituto Mexicano del Seguro Social (IMSS), Guadalajara, Jalisco, Mexico. ${ }^{7}$ Centro Universitario de Ciencias de la Salud, Instituto de
}

Investigación en Ciencias Biomédicas, Universidad de Guadalajara, Guadalajara, Jalisco, Mexico.

\section{Acknowledgements}

This work was supported by grant from the Consejo Nacional de Ciencia y Tecnología, Fondo SEP-CONACYT CB-2013-01 (222205).

\section{Compliance with ethical guidelines}

\section{Competing interests}

The author(s) declare that they have no competing interests.

Received: 2 June 2015 Accepted: 24 August 2015

Published online: 04 September 2015

\section{References}

1. Bole-Feysot C, Goffin V, Edery M, Binart N, Kelly PA (1998) Prolactin (PRL) and its receptor: actions, signal transduction pathways and phenotypes observed in PRL receptor knockout mice. Endocr Rev 19(3):225-268

2. Hu ZZ, Meng J, Dufau ML (2001) Isolation and characterization of two novel forms of the human prolactin receptor generated by alternative splicing of a newly identified exon 11. J Biol Chem 276(44):41086-41094

3. Kline JB, Roehrs H, Clevenger CV (1999) Functional characterization of the intermediate isoform of the human prolactin receptor. J Biol Chem 274(50):35461-35468

4. Trott JF, Hovey RC, Koduri S, Vonderhaar BK (2003) Alternative splicing to exon 11 of human prolactin receptor gene results in multiple isoforms including a secreted prolactin-binding protein. J Mol Endocrinol 30(1):31-47

5. Welsch CW, Nagasawa H (1977) Prolactin and murine mammary tumorigenesis: a review. Cancer Res 37(4):951-963

6. Sakamoto K, Triplett AA, Schuler LA, Wagner KU (2010) Janus kinase 2 is required for the initiation but not maintenance of prolactin-induced mammary cancer. Oncogene 29(39):5359-5369

7. Yamauchi T, Yamauchi N, Ueki K, Sugiyama T, Waki H, Miki H, Tobe K, Matsuda S, Tsushima T, Yamamoto T et al (2000) Constitutive tyrosine phosphorylation of ErbB-2 via Jak2 by autocrine secretion of prolactin in human breast cancer. J Biol Chem 275(43):33937-33944

8. Perks CM, Keith AJ, Goodhew KL, Savage PB, Winters ZE, Holly JM (2004) Prolactin acts as a potent survival factor for human breast cancer cell lines. Br J Cancer 91(2):305-311

9. Savli H, Szendroi A, Romics I, Nagy B (2008) Gene network and canonical pathway analysis in prostate cancer: a microarray study. Exp Mol Med 40(2):176-185

10. Tan SH, Dagvadorj A, Shen F, Gu L, Liao Z, Abdulghani J, Zhang Y, Gelmann EP, Zellweger T, Culig Z et al (2008) Transcription factor Stat5 synergizes with androgen receptor in prostate cancer cells. Cancer Res 68(1):236-248

11. Clendenen TV, Arslan AA, Lokshin AE, Liu M, Lundin E, Koenig KL, Berrino F, Hallmans G, Idahl A, Krogh V et al (2013) Circulating prolactin levels and risk of epithelial ovarian cancer. Cancer Causes Control CCC 24(4):741-748

12. Ascencio-Cedillo R, Lopez-Pulido El, Munoz-Valle JF, Villegas-Sepulveda N, Del Toro-Arreola S, Estrada-Chavez C, Daneri-Navarro A, Franco-Topete R, Perez-Montiel D, Garcia-Carranca A et al (2014) Prolactin and prolactin receptor induction in cervical intraepithelial neoplasia and cancer. Pathol Oncol Res POR

13. Chen CL, Hsieh FC, Lieblein JC, Brown J, Chan C, Wallace JA, Cheng G, Hall BM, Lin J (2007) Stat3 activation in human endometrial and cervical cancers. Br J Cancer 96(4):591-599

14. Plotnikov A, Varghese B, Tran TH, Liu C, Rui H, Fuchs SY (2009) Impaired turnover of prolactin receptor contributes to transformation of human breast cells. Cancer Res 69(7):3165-3172

15. Lopez-Pulido El, Munoz-Valle JF, Del Toro-Arreola S, Jave-Suarez LF, BuenoTopete MR, Estrada-Chavez C, Pereira-Suarez AL (2013) High induction of prolactin receptor is associated with cell survival in cervical cancer cells. Cancer Cell Int 13(1):103 
16. Fernandez JG, Rodriguez DA, Valenzuela M, Calderon C, Urzua U, Munroe D, Rosas C, Lemus D, Diaz N, Wright MC et al (2014) Survivin induction promotes VEGF-induced tumor angiogenesis via PI3K/Akt enhanced beta-catenin/Tcf-Lef dependent transcription. Mol Cancer 13:209

17. Bernichtein S, Touraine P, Goffin V (2010) New concepts in prolactin biology. J Endocrinol 206(1):1-11

18. Grayhack JT, Bunce PL, Kearns JW, Scott WW (1955) Influence of the pituitary on prostatic response to androgen in the rat. Bull Johns Hopkins Hosp 96(4):154-163

19. Berinder K, Akre O, Granath F, Hulting AL (2011) Cancer risk in hyperprolactinemia patients: a population-based cohort study. Eur J Endocrinol Eur Fed Endocr Soc 165(2):209-215

20. Soroush AR, Zadeh HM, Moemeni M, Shakiba B, Elmi S (2004) Plasma prolactin in patients with colorectal cancer. BMC Cancer 4:97

21. Bhatavdekar JM, Patel DD, Chikhlikar PR, Shah NG, Vora HH, Ghosh N, Trivedi TI (2001) Ectopic production of prolactin by colorectal adenocarcinoma. Dis Colon Rectum 44(1):119-127

22. Gonzalez-Lucano LR, Munoz-Valle JF, Ascencio-Cedillo R, DominguezRosales JA, Lopez-Rincon G, Del Toro-Arreola S, Bueno-Topete M, Daneri-Navarro A, Estrada-Chavez C, Pereira-Suarez AL (2012) Increased induction of the prolactin receptor is associated with malignant laryngeal tumors. Exp Ther Med 3(4):603-607

23. Sethi BK, Chanukya GV, Nagesh VS (2012) Prolactin and cancer: has the orphan finally found a home? Indian J Endocrinol Metab 16(Suppl 2):S195-S198

24. Yeh YT, Lee KT, Tsai CJ, Chen YJ, Wang SN (2012) Prolactin promotes hepatocellular carcinoma through Janus kinase 2. World J Surg 36(5):1128-1135
25. Macfee MS, McQueen J, Strayer DE (1987) Immunocytochemical localization of prolactin in carcinoma of the cervix. Gynecol Oncol 26(3):314-318

26. Hsu CT, Yu MH, Lee CY, Jong HL, Yeh MY (1992) Ectopic production of prolactin in uterine cervical carcinoma. Gynecol Oncol 44(2):166-171

27. Wang DY, de Stavola BL, Bulbrook RD, Allen DS, Kwa HG, Verstraeten AA, Moore JW, Fentiman IS, Hayward JL, Gravelle IH (1988) The permanent effect of reproductive events on blood prolactin levels and its relation to breast cancer risk: a population study of postmenopausal women. Eur J Cancer Clin Oncol 24(7):1225-1231

28. Hankinson SE, Willett WC, Michaud DS, Manson JE, Colditz GA, Longcope C, Rosner B, Speizer FE (1999) Plasma prolactin levels and subsequent risk of breast cancer in postmenopausal women. J Natl Cancer Inst 91(7):629-634

29. Fuh G, Wells JA (1995) Prolactin receptor antagonists that inhibit the growth of breast cancer cell lines. J Biol Chem 270(22):13133-13137

30. Giuffrida D, Perdichizzi A, Giuffrida MC, La Vignera S, D'Agata R, Vicari E, Calogero AE (2010) Does prolactin induce apoptosis? Evidences in a prostate cancer in vitro model. J Endocrinol Invest 33(5):313-317

31. LaPensee EW, Ben-Jonathan N (2010) Novel roles of prolactin and estrogens in breast cancer: resistance to chemotherapy. Endocr Relat Cancer 17(2):R91-R107

32. Shukla S, Shishodia G, Mahata S, Hedau S, Pandey A, Bhambhani S, Batra S, Basir SF, Das BC, Bharti AC (2010) Aberrant induction and constitutive activation of STAT3 in cervical carcinogenesis: implications in high-risk human papillomavirus infection. Mol Cancer 9:282

33. Shukla S, Mahata S, Shishodia G, Pandey A, Tyagi A, Vishnoi K, Basir SF, Das BC, Bharti AC (2013) Functional regulatory role of STAT3 in HPV16-mediated cervical carcinogenesis. PLoS One 8(7):e67849

\section{Submit your next manuscript to BioMed Central and take full advantage of:}

- Convenient online submission

- Thorough peer review

- No space constraints or color figure charges

- Immediate publication on acceptance

- Inclusion in PubMed, CAS, Scopus and Google Scholar

- Research which is freely available for redistribution

Submit your manuscript at

www.biomedcentral.com/submit

C Biomed Central 